\title{
WASTE MANAGEMENT ANALYSIS AT TPS 3R MANDIRI SEJAHTERA SINGOSARI MALANG
}

\author{
Arna Puji Rakhmawati, Ria A.A Soemitro and I.D.A.A Warmadewanthi \\ Department of Civil Engineering, Sepuluh Nopember Institute of Technology, Surabaya, Indonesia \\ E-Mail: puji.arna@gmail.com
}

\begin{abstract}
TPS 3R Mandiri Sejahtera using reduce, reuse, and recycle principles are established by government to solve the problems of wastes in the area of the district of Singosari, Malang. According to the monitoring and evaluation processes conducted by the Directorate General of Human Settlements, Ministry of Public Works and Public Housing in 2013, it shown that there were several things at the waste management at TPS 3R had been not in accordance with the Guidelines of waste management of Directorate General of Human Settlement. This research aimed to analysis waste management at TPS 3R Mandiri Sejahtera in order to optimize the waste management. This research using descriptive Analysis. The research result showed that the function of existing waste management condition was poor, with score is 167 . The result indicated that by optimizing the service up to 3\% in every year until 2021, the management of TPS 3R needed to add one tricycle, eight workers for separating waste and one worker for transporting waste and to enlarge the area up to $146 \mathrm{~m}^{2}$ from $578 \mathrm{~m}^{2}$ of current area. The potential optimization processes can be conducted by increasing the coverage of services by $44.81 \%$, the amount of waste which could be transported is $22,30 \mathrm{~m}^{3} / \mathrm{day}$.
\end{abstract}

Keywords : TPS 3R, management, optimalization

\section{INTRODUCTION}

The concept of 3R (Reduce, Reuse and Recycle) is oriented in the prevention of waste through reduce, reuse, and recycle. TPS 3R work involving community participation to make waste reduction sustainable and environmentally friendly. 3R waste management concept on a regional scale management is made to serve a community group consisting of at least 100 (one hundred) heads of household but not more than 1 (one) subdistrict.

The object of research was taken at TPS 3R Mandiri Sejahtera in Malang district because TPS 3R has several problems in the management of waste, such as: organization of KSM of waste management does not run properly, the source of clean water is not available at the site, a shortage of labor, and the difficulties to overcome damage of tool costs and modifications. Based on the above conditions, thus there will be two stages: first the analysis of waste management in TPS 3R Mandiri Sejahtera to assess the existing condition to get a score of TPS3R in order to know the position of TPS 3R functioning well or not, second in order to optimize waste management through asset management available and the third is to calculate the potential revenue of TPS 3R with the optimization of waste management.

\section{LITERATURE REVIEW} Waste

The law No. 18 of 2008 on waste management is the remnant of the daily activities of human and / or natural processes in solid forms. While the Government Regulation No. 81 of 2012 has already described the definition of waste according to its type, namely household waste and similar household waste. Household waste is waste from daily activities in a household that does not include specific feces and trash. Household-like waste is household waste which comes from commercial areas, industrial areas, special areas, social facilities, public facilities, and / or other facilities.

From the several definition above, it can be concluded that the definition of garbage is waste that is solid or semi-solid derived from humans, animals, or plants (natural processes) and are in nature of biodegradable and non-biodegradable.

\section{Genarated waste and density}

Generated waste measurement was done by using using Load-Count Analysis method, based on transporting cycle, waste volume, and weight that enter the Transfer Station location or TPS 3R. Waste Density is the comparison between it's weigh and it's volume ( $\mathrm{kg} / \mathrm{m} 3$ ) (Ministry of Public Works, 2013). Waste density is very important in determining the amount of waste. The waste density determination is based on SNI M-36-1991-03 done by weighing the garbage sampled using $100 \mathrm{~cm}$ x $100 \mathrm{~cm}$ x $50 \mathrm{~cm}$ sized box.

\section{The Principle of operation of TPS 3R}

In principle, the establishment of Waste Processing Site TPS 3R is directed to the concept of Reduce, Reuse and Recycle, where there are efforts to reduce waste from the source to the utilization of organic waste as compost material and non-organic components of industrial activity as a secondary material such as plastic, paper, metal, glass and others. Reduce (R1) or waste reduction is an effort to reduce waste generation at the source environment and can even be done since before the waste is generated. Reuse (R2) is reusing materials so that it will not become waste (without going through the process of management), such as reuse of paper , reuse of bottles of "beverage" for water, and use a rechargeable battery and others. Recycle (R3) is implying that recycling a material have not been use used anymore (waste) into other materials after going through a management process such as processing bottles / used plastic into plastic pellets to be printed and become buckets, hanger, pots and so on.

The concept of the implementation of waste reduction is carried out by regional-scale approach. Waste Management of Household Scale and Regions can be seen in Figure 1 Scale of Household Waste Management and Regions (Directorate General of Human Settlement, 2014) 


\section{METHODS}

This study analysis was using descriptive analysis. Descriptive analysis was used to calculate the optimization of waste management at the TPS 3R Mandiri Sejahtera and potential revenue. Process study is shown in the figure below :

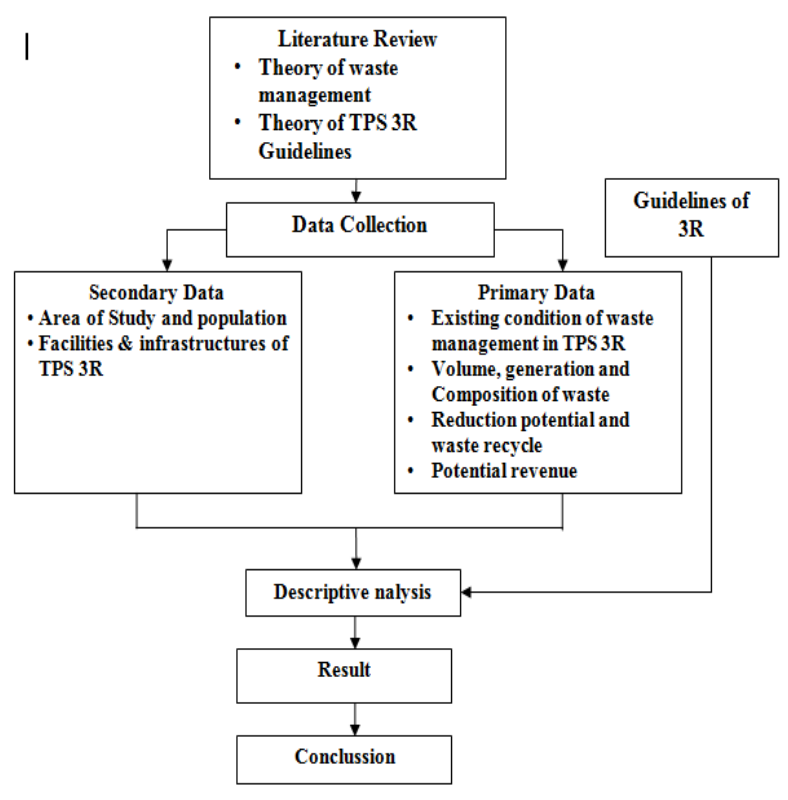

Figure-1. Process Study

\section{RESULT AND DISCUSSIONS}

\section{A. Research object}

Singosari is one of 33 Districts in Malang, which has an overall area of approximately $118.51 \mathrm{~km}^{2}$ or 3.98 percent of the total area of Malang District. Singosari Subdistrict is is located at an altitude of 487 meters above sea level with an average temperature of $22^{\circ} \mathrm{C}-32^{\circ} \mathrm{C}$ and an average rainfall of $349 \mathrm{~mm}$ per year. Singosari Subdistrict boundaries are as follows:

North Side $\quad$ : Subdistrict of Lawang and District of Pasuruan

East Side $\quad$ :Subdistrict of Jabung and Subdistrict of Pakir

South Side :Subdistrict of Blimbing of Malang City

West Side : : Subdistric of Karangploso

Geographic location of the village in the subdistrict of Singosari is in the form of plains and slopes with flat topography and hills. In terms of administrative the region of Singosari Subdistrict are divided into 3 (three) Urban-Villages and 14 (fourteen) villages. TPS 3R Mandiri Sejahtera lies in Krajan boro hamlet, watugede village, Subdistrict of Singosari, Distric of Malang. TPS 3R Mandiri Sejahtera was built in 2012 by CV. Zidane Karya with contract value amounting to Rp. 1,132,838,000.

\section{B. TPS 3R Waste Management Evaluation}

The evaluation include location aspect, physical aspect, facility aspect, organizational and investment aspect, social aspect, legal aspect and operational aspect. Evaluation result of waste management at TPS 3R Mandiri Sejahtera:
1. Location aspect is consists of location indicators of TPS 3R Mandiri Sejahtera, land status, and land area. Total points are 9. The Location of TPS 3R is already right that far enough from public houses which has distance about 100-500 meters. Land statue of TPS 3R is grant land from village government, the area is $2000 \mathrm{~m}^{2}$.

2. Physical aspect consists of topography, hydrology, water sources, and the previous land usage. Total points are 10 . The minus point is water sources availability.

3. Facility aspect:

a. Lug of waste.

Consists of lug of waste container placement (organic waste and non organic waste). Total points are 11.

b. Processing Household waste scale

Consists of the composter, composter volume, composter amount, the color of compost, the smell of compost, compost form, the recycled waste of non organic waste and the products. Total points are 0 . There is no waste reduce from household. The principles of 3R are not used by peoples in Watugede village.

c. Waste processing on region scale

Consists of transportation, transportation models, used technology of waste recycling, composting technology, composting tools, capacity of TPS 3R, Service coverage, the color of compost, the smell of compost and the products. Total points are 26. More than $50 \%$ operation are running as planned.

4. Organizational and investment aspect consist of institution model, organizational structure, legal, investment, funds allocation, and financial report. Total points are 57. The minus points are from organizational structure that isn't running well and financial report do not regularly booked.

5. Social aspect is consist of citizen involvement, community groups, and community meetings frequency. Total points are 9. Social participation is represented by groups. Community meeting just one time for a year.

6. Legal aspect consist of regulation. Total points are 10.

7. Operational aspects consist of operational monitoring evaluation and indicators of operating monitoring evaluation. Total points are 30 .

From those evaluation points will show the category of waste management. Evaluation of current condition use guidelines 3R from Directorate General of Human Settlements. The Result of calculation is 167 points, so the waste management in TPS 3R Mandiri Sejahtera include in less effective category. There are some categories of TPS 3R evaluation result:

1. Effective : $225-311$ points

2. Less Effective : $139-225$ points

3. Not effective : $51-138$ points

The minus point on the aspects such as :

1. Waste Management of Household Scale. There are no reduction waste in household scale and no recycled products. 
2. The organization. KSM not optimal due to members whose no longer work in the organization.

3. Financial reports. There are several financial report are not recorded in detail such as income and maintenance cost.

\section{Waste Reception Analysis}

TPS 3R Mandiri Sejahtera receive waste from Watugede villagers, Tamanharjo Residence, and industries plastic waste. Observation result of daily average of waste at TPS 3R Mandiri Sejahtera without industries plastic waste is $13,61 \mathrm{~m}^{3}$. Waste transporting vehicles use pickup truck and tricycle which have $5 \mathrm{~m}^{3}$ and $2.5 \mathrm{~m}^{3}$ capacity.

Tabel-1 Weekly Waste Reception at TPS 3R Mandiri Sejahtera

\begin{tabular}{|r|l|r|}
\hline No & Waste Source & Waste Volume $\left(\mathrm{m}^{3} / 6\right.$ days $)$ \\
\hline 1 & Watugede Village & 53.94 \\
\hline 2 & Tamanharjo Residence & 27.66 \\
\hline 3 & Industries Plastic Waste & 14 \\
\hline \multicolumn{2}{|c|}{ Total Weekly Volume Received } & $95.6 \mathrm{~m}^{3}$ \\
\hline
\end{tabular}

From Table-1 above, TPS 3R Mandiri Sejahtera receive waste $95.6 \mathrm{~m}^{3}$ in a week or $15.94 \mathrm{~m}^{3}$ in a day.

Table-2. The Observation of Waste Density at TPS 3R Mandiri Sejahtera

\begin{tabular}{|l|c|c|c|c|c|c|}
\hline \multicolumn{1}{|c|}{ Date } & $\begin{array}{c}\text { Test } \\
\text { box } \\
\text { vol } \\
\left(\mathrm{m}^{3}\right)\end{array}$ & $\begin{array}{c}\text { Test } \\
\text { box } \\
\text { weight } \\
(\mathrm{kg})\end{array}$ & $\begin{array}{c}\text { Total } \\
\text { weight } \\
(\mathrm{kg})\end{array}$ & $\begin{array}{c}\text { Waste } \\
\text { weight } \\
(\mathrm{Kg})\end{array}$ & $\begin{array}{c}\text { Waste vol } \\
\text { in test box } \\
\left(\mathrm{m}^{3}\right)\end{array}$ & $\begin{array}{c}\text { Density } \\
\left(\mathrm{kg} / \mathrm{m}^{3}\right)\end{array}$ \\
\hline Mon, 7 September 2015 & 0,5 & 12 & 93 & 81 & 0.45 & 180.00 \\
\hline Tue, 8 September 2015 & 0,5 & 12 & 103 & 91 & 0.55 & 165.45 \\
\hline Wed, 9 September 2015 & 0,5 & 12 & 98 & 86 & 0.43 & 200.00 \\
\hline Thu, 10 September 2015 & 0,5 & 12 & 121 & 109 & 0.54 & 201.85 \\
\hline Fri, 11 September 2015 & 0,5 & 12 & 97 & 85 & 0.45 & 188.89 \\
\hline Sat, 12 September 2015 & 0,5 & 12 & 80 & 68 & 0.40 & 170.00 \\
\hline Mon, 14 September 2015 & 0,5 & 12 & 90 & 78 & 0.48 & 162.50 \\
\hline Tue, 15 September 2015 & 0,5 & 12 & 103 & 91 & 0.50 & 182.00 \\
\hline Average Density & \multicolumn{5}{|l|}{} \\
\hline
\end{tabular}

From Table-2 above, the average of waste density at TPS 3R Mandiri Sejahtera is $181.34 \mathrm{~kg} / \mathrm{m}^{3}$. TPS 3R Mandiri Sejahtera serves about 810 family, then in a family consist of three members. So it can be calculated that $8.99 / 2550=0.00353 \mathrm{~m}^{3}$. Every person produces $0.00353 \mathrm{~m}^{3}$ or $0.67 \mathrm{~kg}$ of waste in a day.

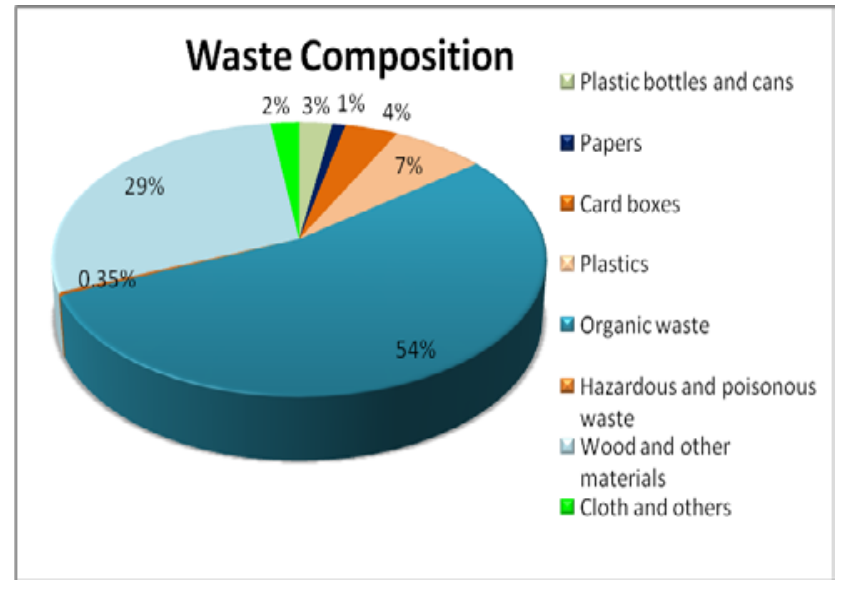

Figure-2. Waste Composition
According to SNI 19-3964-1994 about sampling and calculation method of waste composition from urban areas, from $100 \mathrm{~kg}$ of waste sampling the result is described as the pie diagram above. The highest percentage is organic waste and the smallest percentage is hazardous and poisonous waste.

\section{Population Growth and Waste Analysis}

From Central Bureau of Statistic and District Office Data (BPS), the population of Watugetede village as described on table below.

Table-3 Watugede Population Data

\begin{tabular}{|l|l|}
\hline Year & Population \\
\hline 2008 & 5854 \\
\hline 2009 & 5979 \\
\hline 2010 & 6271 \\
\hline 2011 & 6404 \\
\hline 2012 & 6482 \\
\hline 2013 & 8836 \\
\hline 2014 & 8907 \\
\hline
\end{tabular}

To determine the population growth projection, some methods are used. Arithmetic, Geometric, and Least Square Method.

Table-4 Correlation Coefficient:

\begin{tabular}{|c|l|c|}
\hline No & Calculation Method & Coefficient \\
\hline 1 & Arithmetic & 0,404 \\
\hline 2 & Geometric & 0,893 \\
\hline 3 & Least Square & 0,879 \\
\hline
\end{tabular}

Because of the correlation coefficient of Geometric Method close to one (1), so this method is used.

$\mathrm{Pn}=\mathrm{P}(1+\mathrm{r})^{\mathrm{n}}$

Pn : Population year (n)

$\mathrm{P}$ : Population

n : Year

$\mathrm{r}$ : Population growth ratio

Table-5 Population Projection

\begin{tabular}{|c|c|}
\hline Year & Population Projection \\
\hline 2015 & 9511 \\
\hline 2016 & 10156 \\
\hline 2017 & 10845 \\
\hline 2018 & 11581 \\
\hline 2019 & 12366 \\
\hline 2020 & 13205 \\
\hline 2021 & 14100 \\
\hline
\end{tabular}

From that population growth projection, the waste projection can be calculated. The calculate use the data that produce waste is $0.0037 \mathrm{~m}^{3} /$ person/day in Table-6.

Table-6 Projection of Waste Volume in Watugede 
The 2nd International Conference on Civil Engineering Research (ICCER) 2016

"Contribution of Civil Engineering toward Building Sustainable City"

\begin{tabular}{|c|c|c|}
\hline Year & Population & Waste Generated \\
\hline 2015 & 9511 & 33.57 \\
\hline 2016 & 10156 & 35.85 \\
\hline 2017 & 10845 & 38.28 \\
\hline 2018 & 11581 & 40.88 \\
\hline 2019 & 12366 & 43.65 \\
\hline 2020 & 13205 & 46.61 \\
\hline 2021 & 14100 & 49.77 \\
\hline
\end{tabular}

\begin{tabular}{|c|c|c|c|c|c|c|}
\hline Year & $\begin{array}{c}\text { Separated } \\
\text { Waste(m } \\
\text { day })\end{array}$ & $\begin{array}{c}\text { Worker } \\
\text { Capacit } \\
\text { y/hour }\end{array}$ & Person & $\begin{array}{c}\text { Work } \\
\text { Hours }\end{array}$ & $\begin{array}{c}\text { Output } \\
\left(\mathrm{m}^{3} / \text { day }\right)\end{array}$ & $\begin{array}{c}\text { Worker } \\
\text { Addition }\end{array}$ \\
\hline 2015 & 13.61 & 0.3125 & 4 & 7 & 8.75 & 0 \\
\hline 2016 & 15.30 & 0.3125 & 6 & 7 & 13.13 & 2 \\
\hline 2017 & 17.17 & 0.3125 & 7 & 7 & 15.31 & 1 \\
\hline 2018 & 19.25 & 0.3125 & 8 & 7 & 17.50 & 1 \\
\hline 2019 & 21.55 & 0.3125 & 9 & 7 & 19.69 & 1 \\
\hline 2020 & 24.10 & 0.3125 & 10 & 7 & 21.88 & 1 \\
\hline 2021 & 26.91 & 0.3125 & 12 & 7 & 26.25 & 2 \\
\hline
\end{tabular}

Based on table 6 projection of waste volume in watugede in 2015 are $33.57 \mathrm{~m}^{3}$, in 2016 are 35.85, in 2017 are 38.28 etc. It will increase every year. According to 2014 population data of watugede village:

Total inhabitant $\quad: 8907$

Serviced inhabitant $\quad: 2400$ (800 family)

Total services TPS 3R $\quad: 26.95 \%$

With current services, TPS 3R Mandiri Sejahtera only receives $26.95 \%$ or $8.99 \mathrm{~m}^{3}$ from total amount waste that can be received. There are about $73.05 \%$ from total Watugede waste that cannot be serviced.

\section{TPS 3R Mandiri Sejahtera Service Capacity}

\section{Analysis}

\section{Waste Separation Capacity Analysis}

The purpose of waste separation capacity analysis at TPS 3R Mandiri Sejahtera to get information of waste management by using existing assets at TPS 3R.

Table-7 Waste Reception Volume per Day

\begin{tabular}{|c|l|c|c|}
\hline No & \multicolumn{1}{|c|}{ Waste source } & Waste volume per day & Waste Composition \\
\hline 1 & Watugede village & 8.99 & Household waste \\
\hline 2 & Tamanharjo Residence & 4.61 & Household waste \\
\hline 3 & Industrial plastic waste & 2.33 & Plastic waste \\
\hline \multicolumn{2}{|c|}{ Total } & 15.93 & \\
\hline
\end{tabular}

From the observation, effective working hour for separation process is 7 hours a day and 6 days a week. The capacity of each separation worker is described as the table below.

Table-6 Separation Worker Capacity TPS 3R Mandiri Sejahtera

\begin{tabular}{|c|c|c|l|c|c|c|c|}
\hline No & Worker & $\begin{array}{c}\text { Daily load } \\
\left(\mathrm{m}^{3}\right)\end{array}$ & Job details & $\begin{array}{c}\text { Capacity/w } \\
\text { orker/hour }\end{array}$ & $\begin{array}{c}\text { Work } \\
\text { hour }\end{array}$ & Worker & $\begin{array}{c}\text { Capacity per } \\
\text { day }\end{array}$ \\
\hline 1 & $\begin{array}{c}\text { Group } \\
\mathrm{A}\end{array}$ & 13.60 & $\begin{array}{l}\text { Watugede; } \\
\text { Tamanharjo } \\
\text { waste }\end{array}$ & 0.375 & 7 & 4 & 10.5 \\
\hline 2 & $\begin{array}{c}\text { Group } \\
\text { B }\end{array}$ & 2.33 & $\begin{array}{l}\text { Industrial } \\
\text { plastic waste }\end{array}$ & 0.083 & 7 & 4 & 2.324 \\
\hline Total
\end{tabular}

From the table above, everyday there is about 3.1 $\mathrm{m}^{3}$ per day of waste unable to be separated. Then those waste become additional load on next day. That's why TPS 3R Mandiri Sejahtera difficult to expand its capacity. For optimum separation process, a worker is added, so not separated waste become $0.475 \mathrm{~m}^{3}$ per day.

Table-8 Waste Separation Worker Needs

Based on Table 8. the workers addition can be carried out starting in 2016 by adding two workers, then at 2017 until 2020 need one worker addition each year. And in 2021 need two worker.

\section{Watugede Waste Pick Up Service Analysis}

The current waste transportation capacity and calculation and observation pickup cycle can be seen as follow :

Table-9 Current Waste Transportation Capacity TPS 3R Mandiri Sejahtera

\begin{tabular}{|c|c|c|c|c|c|c|c|c|}
\hline No & Vehicle & Worker & Capacity & $\begin{array}{c}\text { Pick up } \\
\text { time } \\
\text { (Hours) }\end{array}$ & $\begin{array}{c}\text { Available } \\
\text { work } \\
\text { hours }\end{array}$ & $\begin{array}{l}\text { Unused } \\
\text { work } \\
\text { hours } \\
\text { (Jam) }\end{array}$ & $\begin{array}{l}\text { Max pick up } \\
\text { capacity } \\
\left(\mathrm{m}^{3}\right)\end{array}$ & $\begin{array}{l}\text { Piek } \\
\text { up } \\
\text { cycle } \\
\text { order }\end{array}$ \\
\hline \multirow[t]{2}{*}{1} & $\begin{array}{l}\text { Pickup } \\
\text { truck }\end{array}$ & 2 & 5 & 2.5 & 5 & 2.5 & 5 & 1 \\
\hline & $\begin{array}{l}\text { Pickup } \\
\text { truck }\end{array}$ & 2 & 5 & 2.5 & 2.5 & 0 & 5 & 2 \\
\hline \multirow[t]{2}{*}{2} & Tricycle & 1 & 3 & 1.75 & 5 & 3.25 & 3 & 1 \\
\hline & Tricycle & 1 & 3 & \begin{tabular}{|l|l|}
1.75 \\
\end{tabular} & 3.25 & 1.5 & 3 & 2 \\
\hline \multicolumn{7}{|c|}{ Total pick up capacity } & 16 & \\
\hline
\end{tabular}

Waste transportation at TPS 3R Mandiri Sejahtera used today are 1 pickup and 1 tricycle with loading capacity of each are $5 \mathrm{~m}^{3}$ dan $3 \mathrm{~m}^{3}$ and the total of pick cycle are four at total maximum capacity is $15 \mathrm{~m}^{3}$.

Table-10 Maximizing Waste Pick Up Cycle Calculation

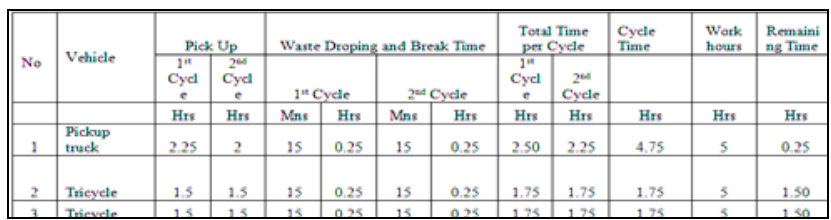

From the table above. by maximizing waste pick up cycle. pick up has 4.75 hours cycle time and tricycles have 1.75 hours each.

Table-11 Vehicle Addition Projection

\begin{tabular}{|c|c|c|c|c|c|}
\hline Year & $\begin{array}{c}\text { Waste } \\
\text { Generated }\end{array}$ & $\begin{array}{c}\text { Waste vol } \\
\text { per day } \\
\left(\mathrm{m}^{3} / \text { day }\right)\end{array}$ & $\begin{array}{c}\text { Service } \\
\text { Rate \% }\end{array}$ & $\begin{array}{c}\text { Picked } \\
\text { up } \\
\text { Waste }\end{array}$ & $\begin{array}{c}\text { Vehicle } \\
\text { Needs }\end{array}$ \\
\hline 2015 & 33.57 & 13.60 & 26.81 & 15 & 0 \\
\hline 2016 & 35.85 & 15.30 & 29.81 & 15 & 0 \\
\hline 2017 & 38.28 & 17.17 & 32.81 & 15 & 0 \\
\hline 2018 & 40.88 & 19.25 & 35.81 & 15 & 0 \\
\hline 2019 & 43.65 & 21.55 & 38.81 & 17 & 0 \\
\hline 2020 & 46.61 & 24.10 & 41.81 & 24 & 1 \\
\hline 2021 & 49.77 & 26.91 & 44.81 & 24 & 0 \\
\hline
\end{tabular}

Vehicle addition needed in 2021 is one pickup truck.

3. Recovery Factor and Reduction Potential 
The 2nd International Conference on Civil Engineering Research (ICCER) 2016

"Contribution of Civil Engineering toward Building Sustainable City"

There are 4 types of waste that have Recovery Factor (RF) value. they are bottles and can. paper and cardboard. plastic. and wet waste. Waste with RF can be seen in Table 11.

Table-12 TPS 3R Mandiri Sejahtera Recovery Factors

\begin{tabular}{|l|c|c|c|c|c|c|}
\hline $\begin{array}{c}\text { Waste } \\
\text { Component }\end{array}$ & $\begin{array}{c}\text { Waste } \\
\text { Compositi } \\
\text { on (\%) }\end{array}$ & $\begin{array}{c}\text { Waste } \\
\text { Weight } \\
(\mathrm{kg} / \text { day) }\end{array}$ & $\begin{array}{c}\mathrm{RF} \\
(\%)\end{array}$ & $\begin{array}{c}\text { Waste } \\
\text { Reductio } \\
\mathrm{n} \\
(\mathrm{kg} / \text { day) }\end{array}$ & $\begin{array}{c}\text { Waste } \\
\text { Reductio } \\
\mathrm{n} \\
\text { Percenta } \\
\text { ge (\%) }\end{array}$ & $\begin{array}{c}\text { Waste } \\
\text { Residue } \\
(\mathrm{kg} / \text { day) }\end{array}$ \\
\hline $\begin{array}{l}\text { Bottles and } \\
\text { Cans }\end{array}$ & 2,5 & 43.29 & 100 & 43.29 & 2.5 & 0 \\
\hline $\begin{array}{l}\text { Paper and } \\
\text { Cardboard }\end{array}$ & 5 & 86.59 & 100 & 86.59 & 5 & 0 \\
\hline Plastics & 7 & 121.23 & 100 & 121.23 & 7 & 0 \\
\hline $\begin{array}{l}\text { Wet Waste } \\
\text { poisardous } \\
\text { waste }\end{array}$ & 54 & 935.17 & 100 & 935.17 & 52 & 0 \\
\hline $\begin{array}{l}\text { Woods and } \\
\text { others }\end{array}$ & 29 & 502.22 & 0 & 0 & 0 & 502.22 \\
\hline $\begin{array}{l}\text { Clothes and } \\
\text { others }\end{array}$ & 2.15 & 37.23 & 0 & 0 & 0 & 37.23 \\
\hline Total (\%) & 100 & 1731.80 & - & 1186.28 & 66.5 & 545.52 \\
\hline
\end{tabular}

Table-13 TPS 3R Mandiri Sejahtera Waste Reduction Potential

\begin{tabular}{|c|c|c|c|}
\hline Year & Waste Vol & RF (\%) & $\begin{array}{c}\text { Utilized waste } \\
\left(\mathrm{m}^{3} / \text { day }\right)\end{array}$ \\
\hline 2015 & 13.60 & 66.5 & 9.04 \\
\hline 2016 & 15.30 & 66.5 & 10.17 \\
\hline 2017 & 17.17 & 66.5 & 11.42 \\
\hline 2018 & 19.25 & 66.5 & 12.80 \\
\hline 2019 & 21.55 & 66.5 & 14.33 \\
\hline 2020 & 24.10 & 66.5 & 16.03 \\
\hline 2021 & 26.91 & 66.5 & 17.90 \\
\hline
\end{tabular}

Based on Table 13 the utilized waste is $66.5 \%$ of the total waste that come from watugede and tamanharjo residence. In 2015. $9.04 \mathrm{~m}^{3}$ waste is utilized. in 2016 of $10.17 \mathrm{~m}^{3}$. in 2017 of $11.42 \mathrm{~m}^{3}$ and continue to rise until reaching service $44.81 \%$ in 2021 with the amount of utilized waste is $17.90 \mathrm{~m}^{3}$.

\section{Land Needs Analysis for TPS 3R Mandiri Sejahtera. Singosari}

TPST 3R Mandiri Sejahtera in 2014 land requirement to enter the reception area trash. waste sorting. composting and waste storage are as follows:
a. Land acceptance of new waste entry : $5 \mathrm{~m}^{3}$
b. Land of industrial plastic waste reception (per week) : $9 \mathrm{~m}^{3}$
c. Place for waste separation : $18 \mathrm{~m}^{3}$
d. Areas of wet waste separation : $12 \mathrm{~m}^{3}$
e. Areas of sorting of plastic waste from watugede and tamanharjo : $1 \mathrm{~m}^{3}$
f. Area of plastic waste sorting from industrial waste : $14 \mathrm{~m}^{3}$
g. Areas of separation of paper and cardboard: $2 \mathrm{~m}^{3}$
h. Areas of separation of bottle cans and plastic bottles: $1 \mathrm{~m}^{3}$.
i. Recycling bin storage area : $18.1 \mathrm{~m}^{3}$.

Table-14 Waste Area Needed Projection

\begin{tabular}{|c|c|c|c|}
\hline Year & Current Area & Service Rate (\%) & $\begin{array}{c}\text { Area Needed } \\
(\mathrm{m} 2)\end{array}$ \\
\hline 2015 & 578 & 26.81 & 549 \\
\hline 2016 & 578 & 29.81 & 572 \\
\hline
\end{tabular}

Construction Project Management

\begin{tabular}{|c|c|c|c|}
\hline Year & Current Area & Service Rate (\%) & $\begin{array}{c}\text { Area Needed } \\
(\mathrm{m} 2)\end{array}$ \\
\hline 2017 & 578 & 32.81 & 596 \\
\hline 2018 & 578 & 35.81 & 623 \\
\hline 2019 & 578 & 38.81 & 652 \\
\hline 2020 & 578 & 41.81 & 687 \\
\hline 2021 & 578 & 44.81 & 724 \\
\hline
\end{tabular}

Waste area needed in 2017 until 2021 with service up to $44.81 \%$. Based on the result of the calculation of the total land requirement is $146 \mathrm{~m}^{2}$.

\section{Financial Analysis of Waste Management in TPS 3R Mandiri Sejahtera}

Financial analysis of waste management is needed for continuity of service TPS 3R Mandiri Sejahtera. By the financial analysis is used to calculating investment feasibility.

Table-15 TPS 3R Cash Flow

\begin{tabular}{|c|c|c|}
\hline Year & Income (Rp) & Expense (Rp) \\
\hline 2015 & 277.052 .294 & 226.815 .413 \\
\hline 2016 & 322.025 .394 & 333.694 .211 \\
\hline 2017 & 409.128 .634 & 402.800 .932 \\
\hline 2018 & 474.094 .289 & 468.785 .256 \\
\hline 2019 & 548.520 .203 & 543.407 .547 \\
\hline 2020 & 688.807 .494 & 765.430 .997 \\
\hline 2021 & 794.341 .717 & 623.037 .446 \\
\hline
\end{tabular}

Based on table 14. Surplus income will be happened at 2015 and become deficit at 2020 due to waste area enlargement. Then in 2021 will be surplus 171.304.271 rupiahs.

\section{NPV Analysis}

Net Present Value (NPV) for investment at TPS 3R until 2021 is $\leq 0(-1,081,723,606)$ not feasible.

\section{CONCLUSIONS}

Based on the results of this study the following conclusions are drawn :

1. The function of existing waste management condition at TPS 3R Mandiri Sejahtera is poor with point 167 in the category less function.

2. Optimization of waste management by optimization of available asset at TPS 3R such as land. machines and vehicle.

3. Adding 8 separating workers. 1 transporting workers. 1 vehicle and $146 \mathrm{~m}^{3}$ of land to reach the service target of $50 \%$.

4. $\mathrm{NPV} \leq 0$, not feasible investment.

\section{REFERENCES}

[1] Damanhuri. E. Padmi T. 2010. Waste Management. Bandung.

[2] Directorate General of Human Settlement Ministry of Public Work and Public Housing. 2014. 3R Guidance. Jakarta

[3] Hidayat. M. 2012. Asset Management. Laksbang Pressindo Yogyakarta.Yogyakarta

[4] Ministry of Public Work .2007. Regulation of The Minister of Public Works No. 21/PRT/M/2006 about 
The 2nd International Conference on Civil Engineering Research (ICCER) 2016

"Contribution of Civil Engineering toward Building Sustainable City"

National Policy and Strategy of Waste Management System Development. Jakarta

[5] Ministry of Public Works. 2013. Third Module Basics of Waste Management System. Jakarta 